Repository of the Max Delbrück Center for Molecular Medicine (MDC) Berlin (Germany)

\title{
The subpopulation of microglia sensitive to neurotransmitters/neurohormones is modulated by stimulation with LPS, interferon- $y$, and IL-4
}

Pannell, M., Szulzewsky, F., Matyash, V., Wolf, S.A., Kettenmann, H.

This is the accepted version of the following article:

Pannell, M., Szulzewsky, F., Matyash, V., Wolf, S.A., Kettenmann, H. The subpopulation of microglia sensitive to neurotransmitters/neurohormones is modulated by stimulation with LPS, interferon-\{gamma\}, and IL-4. Glia 62(5): 667-679, 2014.,

which has been published in final form at http://dx.doi.org/10.1002/glia.22633 
The subpopulation of microglia sensitive to neurotransmitters/hormones is modulated by stimulation with LPS, Interferon-y and IL-4

Maria Pannell, Frank Szulzewsky, Vitali Matyash, Susanne A. Wolf and Helmut Kettenmann

Max-Delbrück-Center for Molecular Medicine, 13125 Berlin-Buch, Germany

Corresponding author:

Prof. Dr. Helmut Kettenmann

Cellular Neurosciences

Max Delbrueck Center for Molecular Medicine

Robert-Roessle-Strasse 10

13125 Berlin

Germany

kettenmann@mdc-berlin.de

(49) 30-9406-3325

Number of pages: 25

Number of figures: 6

Number of tables: 4

Word count abstract: 207

Word count introduction: 370

Word count methods: 1048

Word count results: 1214

Word count discussion: 893

Word count references: 400

Word count Figure legends: 846

Total word count: 5183 


\section{Main Points}

We found that subpopulations of acutely isolated or cultured microglia express distinct neurohormone and neurotransmitter receptors. We observed that these subpopulations change in cultured microglial cells when activated indicating that microglia comprise a highly heterogeneous population of cells with respect to their chemosensitivity.

\section{Key Words}

Neurotransmitter receptor, neurohormone receptor, microglia, IFN-gamma, LPS, IL-4 


\section{Abstract}

Neurotransmitters/-hormones have recently been identified as factors controlling the function of microglia, the immune competent cells of the central nervous system. In this study we compared the responsiveness of microglia to neurotransmitters/-hormones. We freshly isolated microglia from healthy adult C57Bl/6 mice and found that only a small fraction (1 - $20 \%)$ responded to the application of endothelin, histamine, substance $P$, serotonin, galanin, somatostatin, angiotensin II, vasopressin, neurotensin, dopamine or nicotine. In cultured microglia from neonatal and adult mice, a similarly small population of cells responded to these neurotransmitters/-hormones. To induce a pro-inflammatory phenotype, we applied LPS or IFN- $y$ to the cultures for $24 \mathrm{~h}$. Several of the responding populations increased, but there was no uniform pattern when comparing adult with neonatal microglia or LPS with IFN- $\gamma$ treatment. IL-4 as an anti-inflammatory substance increased the histamine, substance $P$ and somatostatin sensitive populations only in microglia from adult, but not in neonatal cells. We also found that the expression of different receptors was not strongly correlated indicating that there are many different populations of microglia with a distinct set of receptors. Our results demonstrate that microglial cells are a heterogeneous population with respect to their sensitivity to neurotransmitters/-hormones and that they are more responsive in defined activation states. 


\section{Introduction}

Microglial cells are the resident immune cells of the brain. It is well established that microglial cells are activated by any pathologic event in the brain. They transform from a ramified morphological phenotype into an amoeboid form. Activated microglia typically increase their phagocytic activity, release proinflammatory cytokines, migrate to the site of injury or increase the expression of the MHCll molecule for antigen presentation. Despite the notion that the morphological transformation is a common indicator of their activation, the functional changes can be quite distinct with respect to the type of pathology and the pathological progression (Hanisch and Kettenmann 2007). We have recently demonstrated that (morphologically activated) microglial cells in a mouse model of Alzheimer's disease decrease their phagocytic activity coincident with the appearance of plaques (Krabbe et al. 2013).

Microglial activation is controlled by a plethora of different factors. One can distinguish between 'on signals', which are newly appearing signals such as bacterial cell wall components during infection, and 'off signals' which disappear or are down-regulated (Biber et al. 2007). Neurotransmitters can act as such 'off signals' for microglia (Pocock and Kettenmann 2007). A series of studies has demonstrated that microglial cells express a large variety of transmitter and hormone receptors, which control distinct microglial functions. Functional receptors for glutamate, GABA, noradrenalin, dopamine, ATP and serotonin have been identified and have been shown to modulate distinct microglial activities (Kettenmann et al. 2011). Activation of the P2Y12 purinergic receptor induces microglial chemotaxis (Haynes et al. 2006) while activation of serotonin receptors promotes process motility but decreases phagocytosis (Krabbe et al. 2012). 
In the present study we tested the functional expression of 7 neurohormone receptors (endothelin, substance $\mathrm{P}$, galanin, somatostatin, angiotensin II, vasopressin and neurotensin), and 4 neurotransmitter receptors (histamine, serotonin, dopamine and the nicotinic acetylcholine agonist nicotine) in microglia freshly isolated from adult mice and in cultured neonatal and adult microglia. In order to mimic pro- and anti-inflammatory phenotypes in cultured microglia, we also treated neonatal and adult cultures with LPS, interferon gamma (IFN $\gamma$ ) and IL-4. Since most of the receptors which we studied, with the exception of nicotine, trigger InsP3-mediated release of calcium from internal stores, we employed calcium imaging to investigate their function during physiological and pathological conditions. 


\section{Methods}

\section{Preparation of acutely isolated microglia}

Microglia from adult C57BL/6 mice (P49-56) were acutely isolated and purified for calcium imaging using magnetic activated cell sorting (MACS). Microglia were isolated from cell suspensions using magnetic CD11b microbeads from Miltenyi Biotech (Bergisch Gladbach, Germany), according to the manufacturer's instructions and as previously described (Nikodemova and Watters 2012). In brief, adult mice were sacrificied by cervical dislocation and the brain was removed. After removal of the cerebellum and olfactory bulbs, the remaining cortex and midbrain was cut into small pieces $\left(1 \mathrm{~mm}^{3}\right)$ and dissociated using the Miltenyi Biotec Neural Tissue Dissociation Kit (Trypsin). After dissociation using a glass Pasteur pipette, the suspension was passed through a $40 \mu \mathrm{m}$ cell strainer followed by centrifugation for $10 \mathrm{mins}$ at $300 \mathrm{~g}$ and $4^{\circ} \mathrm{C}$ to obtain a single cell suspension. The cell suspension was then incubated for 15mins with Miltenyi Biotec myelin removal beads, followed by magnetic separation using LS columns, with 2 columns used per brain. Following myelin removal, the myelin free flow-through was incubated with CD11b beads for 15mins, and the cell suspension was applied to an MS column (Miltenyi Biotec) and washed three times with HBSS/0.5\% BSA/2mM EDTA. Labelled CD11b positive cells (microglia) within the column were then flushed out and plated onto glass coverslips, followed by 15 minutes incubation in DMEM medium to allow adherence. Calcium imaging was then carried out as described below.

\section{Preparation of cultured microglia}


Primary microglia cultures were prepared from the cerebral cortex and midbrain of newborn C57BL/6 mice (P0-P3) as described previously (Giulian and Baker 1986). The microglia were seeded at $1-1.5 \times 10^{5}$ cells per glass coverslip (14 mm diameter). Cultures usually contained $>95 \%$ microglia as detected by isolectin B4 (Griffonia simplicifolia) and were used for experiments within 1 day after plating.

Microglia were also cultured from adult mice (P49-56) as previously described in detail (Scheffel et al. 2012). Briefly, cortical and midbrain tissue was freed of blood vessels and meninges in Hank's balanced salt solution (HBBS), mechanically dissociated into $1 \mathrm{~mm}^{3}$ pieces and trypsinized in $1 \%$ trypsin and $0.05 \%$ deoxyribonuclease for $5 \mathrm{~min}$ at room temperature, as described for neonatal microglia elsewhere (Giulian and Baker 1986). Digested tissue was dissociated using a fire-polished pipette and washed twice in HBBS. Cells were then plated on a confluent monolayer of PO astrocytes in $75 \mathrm{~cm}^{2}$ flasks. The feeder layer of astrocytes was depleted of neonatal microglial cells using clodronate $(200 \mu \mathrm{g} / \mathrm{ml})$ before the adult microglia were added. The adult mixed glial cultures received fresh complete DMEM medium every other day and were treated with 33\% L929-conditioned medium after 7 days or once cells became confluent. Microglia were shaken off 1 week later and were used for experiments within 1 day of plating.

\section{Activation of cultured microglia}

To induce a pro-inflammatory phenotype, microglia cultured from neonatal and adult cells were incubated with $100 \mathrm{ng} / \mathrm{ml}$ lipopolysaccaride (LPS) (Enzo, New York, NY, USA) or $20 \mathrm{U} / \mathrm{ml}$ IFN-y (R\&D systems, Minneapolis, MN, 
USA). An anti-inflammatory phenotype was induced by incubating with 30 ng/ml IL-4 (Peprotech, Rocky Hill, NJ, USA). Stimulating agents were added to cultures 5-7 hours after plating microglia on glass coverslips. Incubation was carried out overnight for 18-24 hours.

\section{Calcium imaging}

Freshly isolated cells were loaded with $5 \mu \mathrm{M}$ fluo-4/AM (Invitrogen, Carlsbad, CA, USA) in the presence of the detergent $0.02 \%$ Pluronic F-127 in HEPES buffer which contained (in $\mathrm{mM}$ ) $\mathrm{NaCl}$ 150.0, $\mathrm{KCl} 5.4, \mathrm{MgCl}_{2}$ 1.0, $\mathrm{CaCl}_{2}$ 2.0, HEPES 10.0, glucose 10.0, adjusted with $\mathrm{NaOH}$ to $\mathrm{pH} 7.4$ supplemented with 1\% tomato lectin conjugated Alexa Fluor®594 for $40 \mathrm{~min}$ at room temperature. After staining, coverslips were washed for 10 min in HEPES buffer. Cultured microglia were stained with $5 \mu \mathrm{M}$ fluo-4/AM for $40 \mathrm{~min}$ at room temperature followed by a 10 min wash in HEPES buffer without the addition of tomato lectin. Coverslips were then transferred to a recording chamber and buffer flow was adjusted to 3-4 $\mathrm{ml} / \mathrm{min}$. Fluorescence pictures were taken every $3 \mathrm{~s}$ at $488 \mathrm{~nm}$ excitation wavelength produced by a Polychrome II monochromator (Till Photonics, Martinsried, Germany) using 40x Achroplan water immersion objective (NA 0.75, Zeiss, Jena, Germany). A perfusion system was installed to change the solution within seconds. Before calcium recording from freshly isolated cells, tomato lectin-positive microglia were identified by fluorescence excitation at $560 \mathrm{~nm}$ and emission observed at $630 \mathrm{~nm}$. In order to determine whether cells responded to the application of the test substance, an algorithm was used. This algorithm calculated the average baseline of the calcium signal 1 min before application of the test substance and the peak of the fluorescence signal during application. When 
the peak of the fluorescence signal was at least 4 standard deviations higher than the average baseline, this was considered a positive response. The peak was only counted as positive if it occurred at least $10 \mathrm{~s}$ after the start of application, in order to account for the delay in the concentration change in the chamber. If there was significant bleaching, which resulted in a shift of the baseline, this was corrected for.

\section{Statistical analysis}

All data represent the percentage of cells responding from at least 3 mice for freshly isolated microglia or 3 preparations for cultured microglia. The total number of cells responding to ATP was calculated for all experiments for each condition. The total number of cells responding to a given substance in a given condition was then calculated as a percentage of the ATP responding population. Based on the ability of cells to respond with an elevation of intracellular $\mathrm{Ca}^{2+}$ to the application of neurotransmitters/hormones, every individual cell was categorized as responding or non-responding; subsequently data were collected as categorical variables and the proportions of responding cells were compared between different experimental conditions (adult freshly isolated, untreated adult cultured and neonatal cultured as well as treatment of cultured cells with LPS, IFN or IL4). Since our data are categorical, we cannot use ANOVA with post-hoc correction tests, which are used to analyze normally distributed quantitative variables. Instead we applied chi-squared test for comparison of multiple proportions ( $R$ software, stats, chisq.test function) followed by the post-hoc Marascuillo procedure to test for the significance of differences between pairs of proportions (Marascuilo 
1966). Lower and upper limits of the $95 \%$ confidence interval for a proportion was calculated according to the procedure described by E. B. Wilson (Wilson 1927) using R software (stats, prop.test function) (Verzani 2005), The differences were considered statistically significant at $p<0.05$. 


\section{Results}

\section{Subpopulations of freshly isolated microglia respond to defined}

neurotransmitters/-hormones

We isolated microglia from adult mouse cortex and midbrain by MACS using CD11b microbeads to specifically purify microglia. The cells were loaded with the $\mathrm{Ca}^{2+}$-sensor Fluo-4 for $40 \mathrm{~min}$ and labelled in parallel with $1 \%$ tomato lectin conjugated Alexa Fluor ${ }^{\circledR} 594$ to verify that the cells were microglia. Each neurotransmitter/-hormone was applied for one minute and after a 5 min wash, ATP $(500 \mu \mathrm{M})$ was applied for 30 seconds. We selected only those cells which showed a clear response to ATP which were, in most experiments, all cells in the selected field. Of those cells which responded to ATP, $1 \%$ of cells responded to endothelin application, $10 \%$ to histamine, $26 \%$ to substance $\mathrm{P}, 9 \%$ to serotonin, $14 \%$ to galanin, $11 \%$ to somatostatin, $7 \%$ to angiotensin II, $5 \%$ to vasopressin, $8 \%$ to neurotensin, $6 \%$ to dopamine and $6 \%$ to nicotine with a transient increase in Fluo-4 fluorescence corresponding to an increase in $\mathrm{Ca}^{2+}$. Figure $1 \mathrm{~A}-\mathrm{K}$ shows examples of a positive response for each substance and figure $1 \mathrm{~L}$ shows the percentage of freshly isolated adult microglia responding to each substance. Table 1 describes the mean integral and amplitude of the calcium responses for each substance compared to the ATP response, as well as the duration of the calcium transients. The mean amplitudes and integral (which combines the data of amplitude and duration) were typically smaller when compared to the ATP response, while the duration was calculated as the mean number of seconds from the beginning of the increase in fluorescence, which was four standard deviations higher than the baseline, to the end of the signal. Figure $2 \mathrm{~A}$ shows images of freshly isolated, as well as neonatal and adult cultured microglia, 
during calcium imaging with neurotensin and ATP as a positive control. Figure 2B shows the corresponding calcium traces for highlighted cells from each preparation.

\section{Subpopulations of cultured neonatal and adult microglia respond to} neuropeptides/-hormones

Endothelin-1, histamine, substance P, serotonin, galanin, somatostatin, angiotensin II, vasopressin, neurotensin, dopamine and nicotine were all applied to cultured neonatal (postnatal day 1) microglia using the same calcium imaging protocol described above for freshly isolated cells. ATP was used as a positive control. Of those cells which responded to ATP, $6 \%$ of cells responded to endothelin application, $2 \%$ to histamine, $9 \%$ to substance $\mathrm{P}$, $22 \%$ to serotonin, $4 \%$ to galanin, $6 \%$ to somatostatin, $5 \%$ to angiotensin II, $8 \%$ to vasopressin, $13 \%$ to neurotensin, $4 \%$ to dopamine and $5 \%$ to nicotine with a transient increase in Fluo-4 fluorescence corresponding to an increase in $\mathrm{Ca}^{2+}$ (Figure 3)

Microglia from adult brain were cultured for 1 week, then shaken off and plated onto glass coverslips after 1 week and tested for functional receptor expression using calcium imaging as before. The cells responding to endothelin $(13 \% ; p<0.001)$ and nicotine $(17 \% ; p<0.001)$ application was significantly higher than the percentage of responders in freshly isolated adult cells (Figure $1 \mathrm{~L})$. The population responding to histamine $(3 \% ; p<0.001)$, to substance $P(1 \% ; p<0.001)$ and to galanin $(6 \% p<0.001)$ was significantly lower than the percentage of freshly isolated cells. The population responding to serotonin $(6 \%)$, to somatostatin $(12 \%)$, to angiotensin II $(11 \%)$, to 
vasopressin (2\%), to neurotensin (6\%), and to dopamine $(7 \%)$ did not significantly differ when compared to freshly isolated adult cells (Figure 4).

Distinct neurotransmitter/-hormone sensitive populations can be increased by treatment with IFN-y, LPS and IL-4

A pro-inflammatory phenotype was induced in cultured neonatal microglia by 18h treatment with $100 \mathrm{ng} / \mathrm{ml}$ LPS or $20 \mathrm{U} / \mathrm{ml}$ IFN-y. An anti-inflammatory phenotype was induced through overnight treatment with $30 \mathrm{ng} / \mathrm{ml} \mathrm{IL-4}$. LPS treatment resulted in a significantly higher population of endothelin, histamine, somatostatin and vasopressin sensitive cells (Figure 3), while IFN-y treatment resulted in a significantly larger histamine, galanin, somatostatin, angiotensin II, vasopressin and dopamine sensitive population and a significant decrease in the serotonin sensitive population (Figure 3). IL-4 treatment did not result in an increase in any of the neurotransmitter/-hormone sensitive populations but led to a significant decrease in the substance $P$, serotonin, neurotensin and nicotine sensitive populations (Figure 3).

Incubation of cultured adult microglia with $100 \mathrm{ng} / \mathrm{ml}$ LPS resulted in a significantly higher population of endothelin, histamine, substance $\mathrm{P}$, serotonin, galanin, somatostatin, angiotensin II and vasopressin sensitive populations (Figure 4). Treatment of adult microglia with $20 \mathrm{U} / \mathrm{ml} \mathrm{IFN-Y}$ resulted in a significant increase in the histamine and neurotensin sensitive populations, and a significant decrease in the serotonin, somatostatin, angiotensin II and nicotine sensitive populations. Responses to all other substances were not significantly different to untreated adult microglia (Figure 4). Treatment of adult microglia with $30 \mathrm{ng} / \mathrm{ml} \mathrm{IL-4} \mathrm{resulted} \mathrm{in} \mathrm{a} \mathrm{significant}$ increase in the substance $\mathrm{P}$ sensitive population and a significant decrease in 
the angiotensin II and dopamine sensitive populations (Figure 4). Table 2 summarises all the results for calcium imaging experiments from freshly isolated and cultured microglia with fold change and significance.

\section{Consecutive application of three neurotransmitters/hormones shows heterogeneity in the expression pattern}

We addressed the question of whether different transmitter receptors are expressed in a coordinated fashion or at random. We therefore applied galanin, somatostatin and angiotensin II to IFN-Y stimulated neonatal microglia since a high amount of cells responded under these conditions. When tested alone, 24,30 and $45 \%$ of the cells responded to application of these substances, respectively. We consecutively applied galanin, somatostatin and angiotensin II to one given cell, with a 5 minute washout in between each substance and a 30 second application of ATP as a positive control at the end of the experiment (Figure 5). We found that $31 \%$ of cells responded to only one ligand, $8 \%$ to two and $2 \%$ to all three. $59 \%$ of cells did not respond at all (except to ATP). Fourteen percent responded to galanin, $3 \%$ to somatostatin and $14 \%$ to angiotensin II alone. The order of application was also changed. We subsequently tested somatostatin, followed by angiotensin II and then galanin; we found that $62 \%$ of cells did not respond to any of the ligands, $18 \%$ to only one, $16 \%$ to two and $3 \%$ to all three. Similarly, when the order of application was switched to angiotensin II - galanin somatostatin, $67 \%$ did not respond, $28 \%$ to 1 ligand, $4 \%$ to 2 and $1 \%$ to all three. The data are summarized in Table 3. Based on the percentage of cells responding to two given transmitters we calculated the probability that they co-respond and compared it to the measured value. These values were fairly 
similar indicating that the expression of the different receptors is independently regulated. When calculating the probability that a cell responds to all three different transmitters, we found that the measured value was higher than the calculated value indicating that there is a low cooperativity of expression for triple sensitive cells. The only exception was seen during the somatostatin - angiotensin - galanin application, where there were an increased percentage of cells to respond to both angiotensin and galanin than to a single response to somatostatin, angiotensin or galanin (Figure 5E). The measured probability was higher at 0.123 compared to the calculated probably at 0.051 (Table 3). This demonstrates that there may be some receptor cooperativity which is not random.

A similar series of experiments was carried out on adult cultured microglia treated with LPS (Figure 6). We consecutively applied endothelin, histamine and substance $P$ since a large amount of LPS stimulated cells responded under these conditions. We also tested the sequence histamine - substance $\mathrm{P}$ - endothelin, and substance $\mathrm{P}$ - endothelin -histamine. We made the same observations as for the neonatal IFN-y stimulated cells. Table 4 contains a summary of the data. Measured probabilities were calculated by dividing the percentage response by 100 . Calculated probabilities are shown in Table 3 and 4 in italics. 


\section{Discussion}

Microglia comprise a heterogeneous population with respect to their responsiveness to neurotransmitterl-hormones

We have studied the microglial $\mathrm{Ca}^{2+}$ response to endothelin, histamine, substance $\mathrm{P}$, serotonin, galanin, somatostatin, angiotensin II, vasopressin, neurotensin, dopamine and nicotine in three different preparations, namely freshly isolated adult cells, cultured adult and neonatal cells. We found that only a subpopulation of less than $20 \%$ of cells responded to any of these ligands, suggesting that small heterogeneous subpopulations of microglia exist that are characterized by distinct functional receptor expression. We found that all three preparations showed a similar functional expression pattern.

In our isolation procedure to obtain freshly isolated microglia, we strip the cells of their processes. If the receptors are predominantly located on the processes, the cells might lose their sensitivity. While we can not exclude that possibility, a study on virally transduced microglia did not provide any evidence that $\mathrm{Ca}^{2+}$ signals are stronger in processes as compared to the soma (Seifert et al. 2011). In addition, we found that cultured microglia both from adult and neonatal tissue also show a similar response pattern as the freshly isolated cells. We thus assume that our data reflect the response pattern of microglia in the tissue.

So far, $\mathrm{Ca}^{2+}$ imaging for the substances we tested has not been performed on naive, resting microglial cells. We previously recorded $\mathrm{Ca}^{2+}$ responses to ATP, endothelin-1, substance $\mathrm{P}$, histamine and serotonin in microglia which were transduced with a retrovirus encoding a calcium sensor, after triggering microglial proliferation by a stab wound in vivo. About half of the ATP- 
sensitive population responded to these four ligands and this population was not altered 42 days after the injection (Seifert et al. 2011). In this preparation one has to take into account that these microglial cells have undergone an activation process and that they may be distinct from naïve microglia. A different approach was used by Eichhoff et al. by delivering the $\mathrm{Ca}^{2+}$ indicator dye Oregon green BAPTA 1 to microglial cells in vivo with an electroporation technique (Eichhoff et al. 2011). They found that $20 \%$ of the cells responded to glutamate, but none to carbachol. The electroporation technique, however, might also have an impact on the properties of the cells.

Other transmitter receptors were studied with the patch-clamp technique in acute slices. About half of the microglial cells in rat or mouse responded to the $\mathrm{GABA}_{B}$ receptor ligand SKF 97541 with the induction of an outwardly rectifying $\mathrm{K}^{+}$conductance (Kuhn et al. 2004). The use of $\mathrm{GABA}_{\mathrm{B}}$ receptorspecific antibodies indicated that the population of $\mathrm{GABA}_{B}$ receptor expressing microglia was lower than $50 \%$ and this discrepancy can be explained by the fact that patch-clampers make an individual selection of cells. In the facial nerve lesion model, activated microglia show an increase in $\mathrm{GABA}_{B}$ receptor expression. Subpopulations of microglial cells also responded to dopamine and adrenergic receptor agonists when studied with the patch-clamp technique in acute slices from postnatal day 8 animals; about a third of the cells responded to dopamine with a change in $\mathrm{K}^{+}$conductance, and a fourth to adrenergic agonists (Farber et al. 2005). Despite differences in the preparation and activation state of the microglia, all of these studies show that only a subpopulation of microglia expresses functional receptors for a given neurotransmitter/neurohormone. Regardless of age, isolation procedure and stimulation, we have been able to support this data and thus conclude 
that microglia constitute a rather heterogeneous cell population with respect to their response to neurotransmitters and neurohormones.

\section{Manipulation of cultured microglia with LPS, IFN-y nor IL-4 alters the functional expression pattern of neurotransmitterl-hormones}

LPS, IFN- $y$ and IL-4 triggered defined changes in the functional expression pattern of the receptors that we studied. The histamine sensitive population increased in both adult and neonatal microglia after treatment with both LPS and IFN-y. We also observed differences between adult and neonatal cultures such as the increase in the angiotensin II sensitive population in adult, but not neonatal LPS treated microglia or the increase in the angiotensin II sensitive population only in neonatal cells after IFN-y treatment. Thus we could not recognize a uniform pattern in the change in chemosensitive microglial populations in different activation paradigms.

\section{Microglia do not show a correlated expression of receptors}

One could speculate that there is one small population of microglia which expresses all the receptors and a large population which does not respond at all. Alternatively, each cell could express a distinct subset resulting in a large number of distinct subpopulations. We addressed this question experimentally and found evidence for the latter. We selected galanin, somatostatin and angiotensin II in IFN-ץ treated neonatal cells, and endothelin, histamine and substance $P$ application in LPS treated adult cells, since under these conditions the percentage of responding cells was much higher as compared to control cells. The probability of a given cell to respond to two transmitters could be calculated by multiplying the probability of the population to respond 
to each of the two, assuming that the expression is not correlated. The actual determined probability value matched that of the predicted value confirming that the expression of galanin, somatostatin and angiotensin II or endothelin, histamine and substance $\mathrm{P}$ is not correlated. One exception to this rule, however, might be angiotensin and galanin, since a high percentage of cells responded to both of these substances when applied in the order somatostatin - angiotensin - galanin. Apart from this observation, only the cell population responding to all three of the tested ligands was slightly higher than that of an uncorrelated expression. This indicates that there is an immense diversity of microglia with respect to their neurotransmitter/-hormone sensitivity.

\section{Acknowledgments}

This project was funded by Deutsche Forschungsgemeinschaft (SFB TR43) and Neurocure. We would also like to thank Irene Haupt for excellent technical assistance and Dr. Marina Matyash for help and advice with the statistical analysis. 


\section{References}

Biber K, Neumann H, Inoue K, Boddeke HWGM. 2007. Neuronal 'On' and 'Off' signals control microglia. Trends in Neurosciences 30(11):596-602.

Eichhoff G, Brawek B, Garaschuk O. 2011. Microglial calcium signal acts as a rapid sensor of single neuron damage in vivo. Biochim Biophys Acta 1813(5):101424.

Farber K, Pannasch U, Kettenmann H. 2005. Dopamine and noradrenaline control distinct functions in rodent microglial cells. Mol Cell Neurosci 29(1):128-38.

Giulian D, Baker TJ. 1986. Characterization of ameboid microglia isolated from developing mammalian brain. The Journal of Neuroscience: The Official Journal of the Society for Neuroscience 6(8):2163-2178.

Hanisch U-K, Kettenmann H. 2007. Microglia: active sensor and versatile effector cells in the normal and pathologic brain. Nature Neuroscience 10(11):13871394.

Haynes SE, Hollopeter G, Yang G, Kurpius D, Dailey ME, Gan WB, Julius D. 2006. The P2Y12 receptor regulates microglial activation by extracellular nucleotides. Nat Neurosci 9(12):1512-9.

Kettenmann H, Hanisch U-K, Noda M, Verkhratsky A. 2011. Physiology of microglia. Physiological reviews 91(2):461-553.

Krabbe G, Halle A, Matyash V, Rinnenthal JL, Eom GD, Bernhardt U, Miller KR, Prokop S, Kettenmann H, Heppner FL. 2013. Functional impairment of microglia coincides with Beta-amyloid deposition in mice with Alzheimer-like pathology. PLoS One 8(4):e60921.

Krabbe G, Matyash V, Pannasch U, Mamer L, Boddeke HWGM, Kettenmann H. 2012. Activation of serotonin receptors promotes microglial injury-induced motility but attenuates phagocytic activity. Brain, Behavior, and Immunity 26(3):419-428.

Kuhn SA, van Landeghem FKH, Zacharias R, FÃarber K, Rappert A, Pavlovic S, Hoffmann A, Nolte C, Kettenmann H. 2004. Microglia express GABA(B) receptors to modulate interleukin release. Molecular and cellular neurosciences 25(2):312-322.

Marascuilo LA. 1966. Large-sample multiple comparisons. Psychol Bull 65(5):28090.

Nikodemova M, Watters JJ. 2012. Efficient isolation of live microglia with preserved phenotypes from adult mouse brain. J Neuroinflammation 9:147.

Pocock JM, Kettenmann H. 2007. Neurotransmitter receptors on microglia. Trends in Neurosciences 30(10):527-535.

Scheffel Jr, Regen T, Van Rossum D, Seifert S, Ribes S, Nau R, Parsa R, Harris RA, Boddeke HWGM, Chuang H-N and others. 2012. Toll-like receptor activation reveals developmental reorganization and unmasks responder subsets of microglia. Glia 60(12):1930-1943. 
Seifert S, Pannell M, Uckert W, FÃarber K, Kettenmann H. 2011. Transmitter- and hormone-activated $\mathrm{Ca}(2+)$ responses in adult microglia/brain macrophages in situ recorded after viral transduction of a recombinant $\mathrm{Ca}(2+)$ sensor. Cell Calcium 49(6):365-375.

Verzani J. 2005. Using R for Introductory Statistics: Chapman and Hall/CRC.

Wilson EB. 1927. Probable Inference, the Law of Succession, and Statistical Inference. Journal of the American Statistical Association 22(158):209-212. 


\section{Figure Legends}

Figure 1 A subpopulation of freshly isolated adult microglia respond to neurotransmitters and neurohormones

Representative examples of intracellular calcium transients induced in freshly isolated adult microglia cells by $60 \mathrm{~s}$ application of endothelin (A), histamine (B), substance $P(C)$, serotonin $(D)$, galanin $(E)$, somatostatin $(F)$, angiotensin II (G), vasopressin $(H)$, neurotensin $(\mathrm{I})$, dopamine $(\mathrm{J})$ and nicotine $(\mathrm{K})$ at the concentration as indicated. After a 5min washout, 500 $\mu \mathrm{M}$ ATP was applied for $30 \mathrm{~s}$ as a positive control. $\mathrm{L}$ shows the percentage of freshly isolated adult microglia to respond to each neurotransmitter/hormone. Data are shown as the proportion of responding cells \pm margin of error for $95 \%$ confidence interval.

Figure 2 Neonatal and adult cultured and freshly isolated adult microglia respond to neurotensin with an increase in intracellular calcium Fluo-4 fluorescence image of neonatal cultured microglia (top row), adult cultured microglia (middle row) and freshly isolated microglia (bottom row) shown at baseline calcium, during application of 100nM neurotensin and during application of $500 \mu \mathrm{M}$ ATP $(\mathrm{A})$. 2B shows the corresponding calcium traces for the regions of interest as indicated by circle in A.

Figure 3 Treatment of neonatal cultured microglia with LPS, IFN- Y and IL-4 has distinct effects on the transmitter and hormone responses 
Percentage of cultured neonatal cells which responded to endothelin (A), histamine $(B)$, substance $P(C)$, serotonin $(D)$, galanin $(E)$, somatostatin $(F)$, angiotensin II (G), vasopressin $(\mathrm{H})$, neurotensin $(\mathrm{I})$, dopamine $(\mathrm{J})$ and nicotine (K). Untreated neonatal microglia (control) are compared to cultures treated with LPS (100ng/ml), IFN-Y (20U/ml) and IL-4 (30ng/ml). Data are presented as the percentage of cells which responded to a given substance (the ATP responsive population is taken as $100 \%$ ) from at least 10 investigated microscopic fields from at least 3 independent cell preparations and statistical significance is shown as ${ }^{* * *}$ for $p \leq 0.001,{ }^{* *}$ for $p \leq 0.01$ and * for $p \leq 0.05$. Data are shown as the proportion of responding cells \pm margin of error for 95\% confidence interval.

Figure 4 Treatment of adult cultured microglia with LPS, IFN- Y and IL-4 has distinct effects on the receptor repertoire

Percentage of cultured adult cells which respond to endothelin (A), histamine $(B)$, substance $P(C)$, serotonin $(D)$, galanin $(E)$, somatostatin $(F)$, angiotensin II (G), vasopressin $(H)$, neurotensin $(\mathrm{I})$, dopamine $(\mathrm{J})$ and nicotine $(\mathrm{K})$. Untreated adult microglia (control) are compared to cultures treated with LPS (100ng/ml), IFN-y (20U/ml) and IL-4 (30ng/ml). Data are presented as the percentage of cells which responded to a given substance (the ATP responsive population is taken as $100 \%$ ) from at least 10 investigated microscopic fields from at least 3 independent cell preparations and statistical significance is shown as ${ }^{* * *}$ for $p \leq 0.001,{ }^{* *}$ for $p \leq 0.01$ and * for $p \leq 0.05$. Data are shown as the proportion of responding cells \pm margin of error for 95\% confidence interval. 
Figure 5 Consecutive application of galanin, somatostatin and angiotensin II shows heterogeneity in the expression pattern

Calcium imaging for these substances was carried out on IFN-Y treated neonatal microglia. An example trace for each experimental sequence shows (A) the cell responds to both galanin and angiotensin II after the sequence galanin - somatostatin - angiotensin II, (B) a response to somatostatin only after the application sequence somatostatin - angiotensin II - galanin, (C) a response to angiotensin II and somatostatin after the sequence angiotensin II - galanin - somatostatin. (D, E, F) Bar charts show the probability that a cell will respond to each given substance, alone and in combination with a response from one or more other substances. The probability changes depending on the order of application.

Figure 6 Consecutive application of endothelin, histamine and substance $P$ shows heterogeneity in the expression pattern

Calcium imaging for these substances was carried out on LPS treated adult microglia. An example trace for each experimental sequence shows $(A)$ the cell responds only to endothelin after the sequence endothelin - histamine substance $P,(B)$ a response to histamine and endothelin after the application sequence histamine - substance $P$ - endothelin, (C) a response to all 3 ligands after the sequence substance $P$ - endothelin - histamine. (D, E, F) Bar charts show the probability that a cell will respond to each given 
substance, alone and in combination with a response from 1 or more other substances. The probability changes depending on the order of application.

\section{Table 1}

Mean integral, amplitude and duration of neurotransmitter/-hormone induced $\mathrm{Ca}^{2+}$ transients for freshly isolated adult microglia.

\section{Table 2}

A summary of fold change and statistical significance (decoded as greyscale) of microglial populations responsive to the specific ligands in LPS, IFN-Y and IL-4 treated neonatal and adult cultured cells compared to controls.

\section{Table 3}

Probability of a single or a combination of responses to galanin, somatostatin and angiotensin II depending on the order of application. Measured probabilities were calculated by dividing the percentage response by 100 . Calculated probabilities are shown in italics.

\section{Table 4}

Probability of a single or a combination of responses to endothelin, histamine and substance $\mathrm{P}$ depending on the order of application. Measured probabilities were calculated by dividing the percentage response by 100 . Calculated probabilities are shown in italics. 
Figure 1
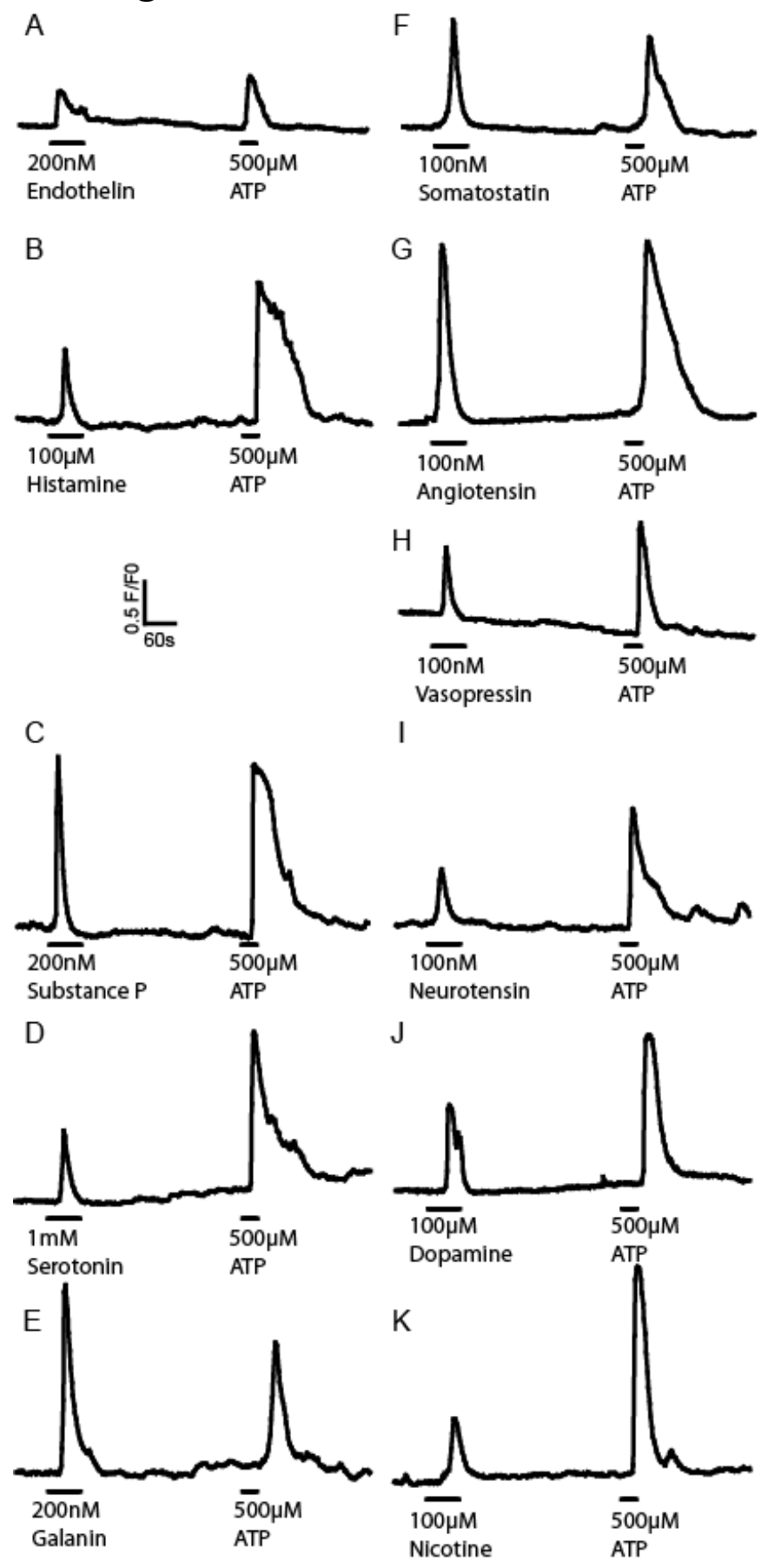

L

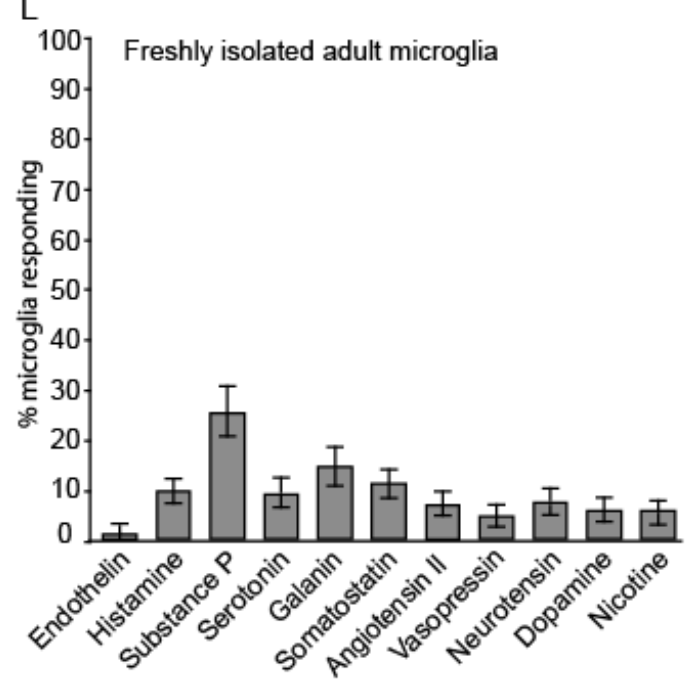


Figure 2

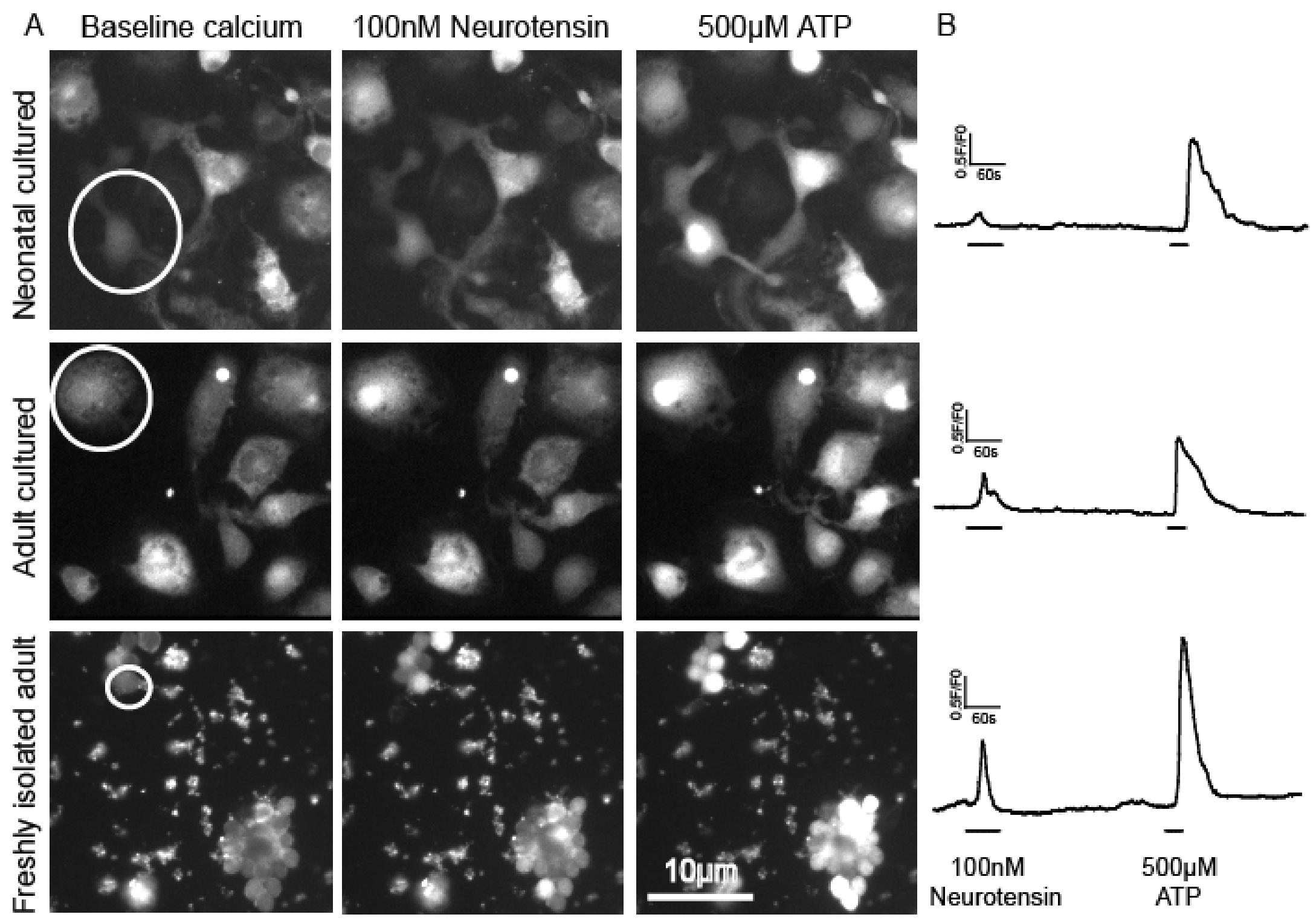


Figure 3
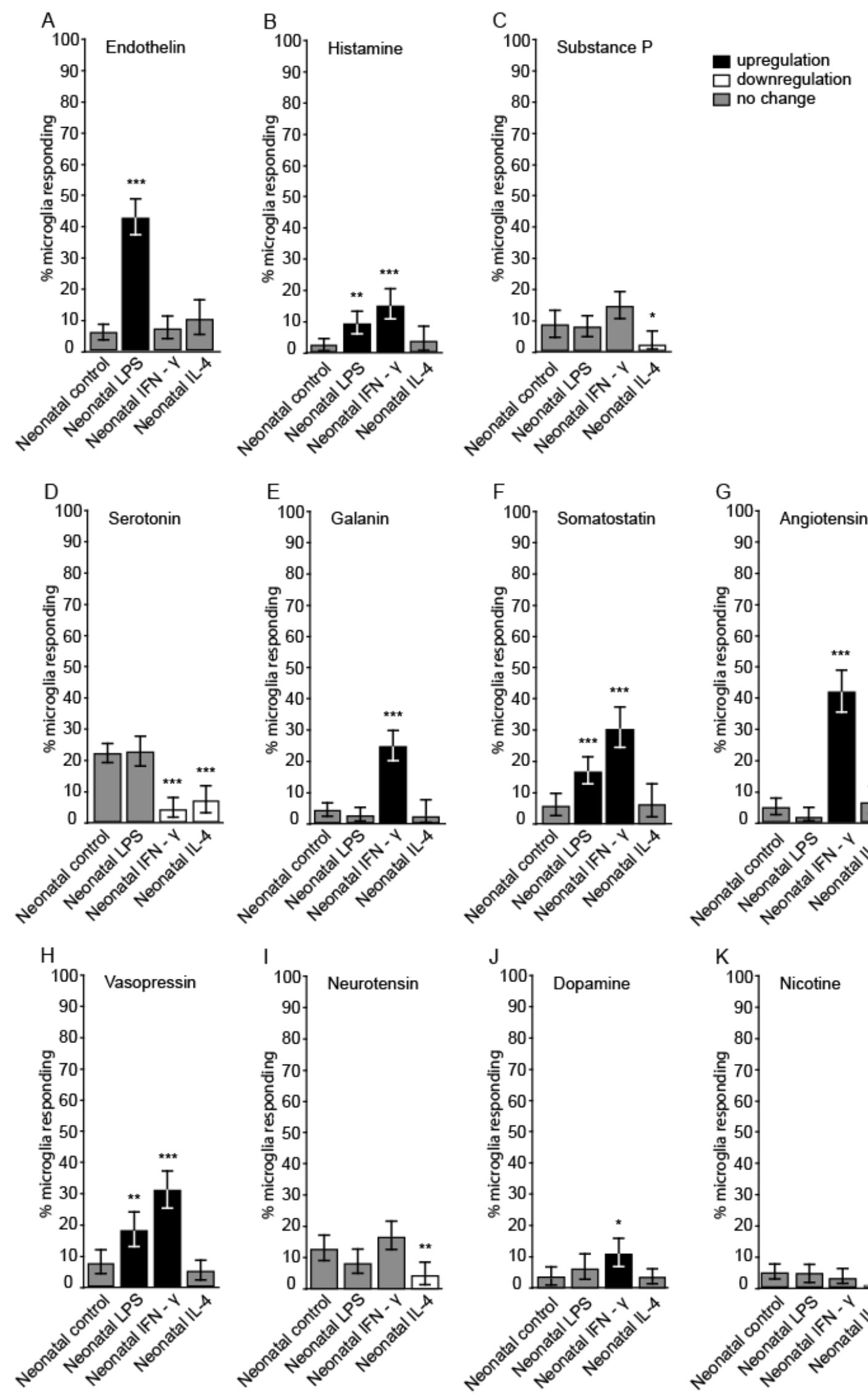

E

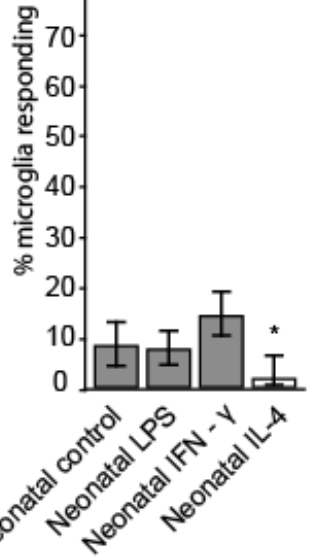

$\square$ no change
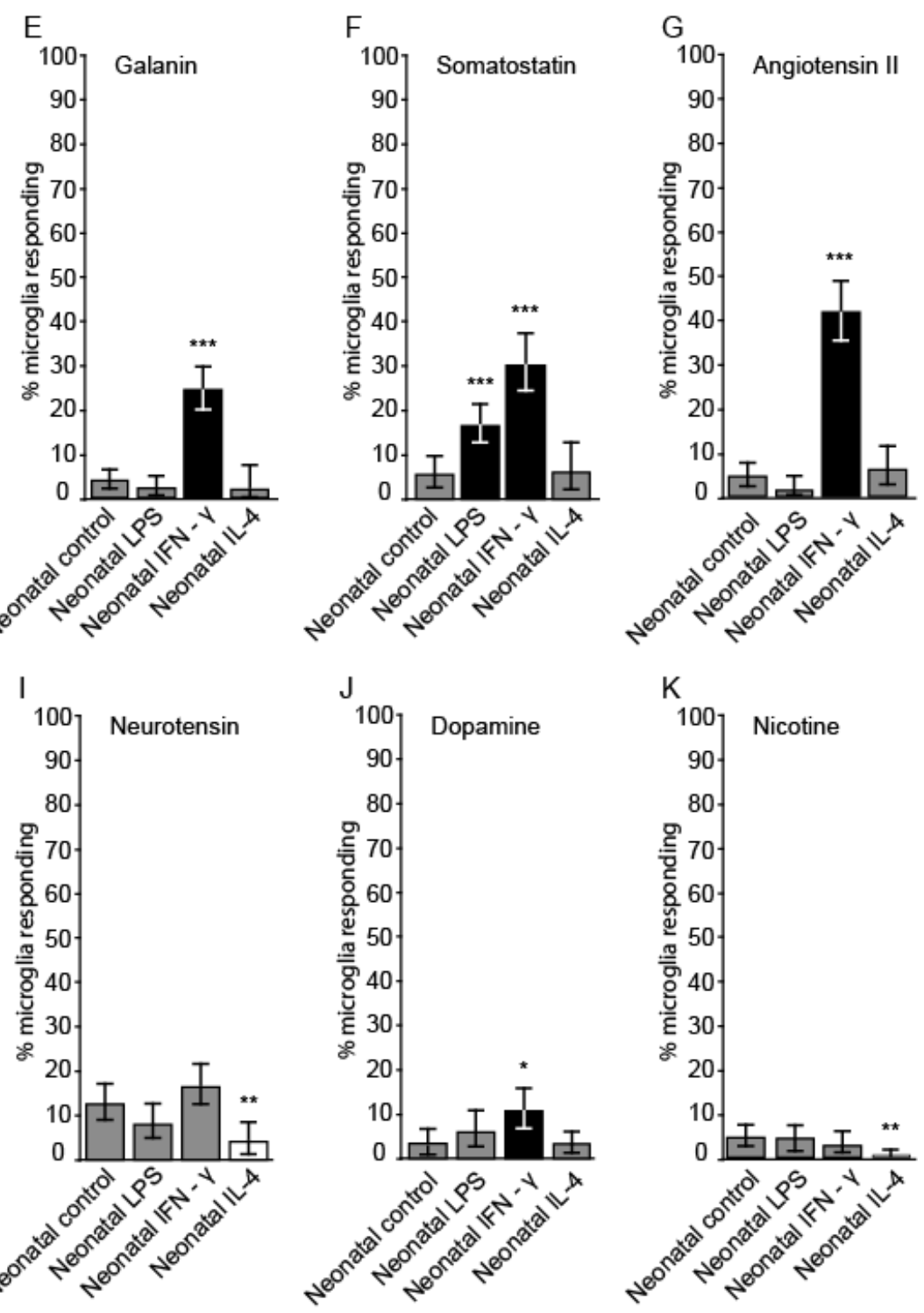
Figure 4
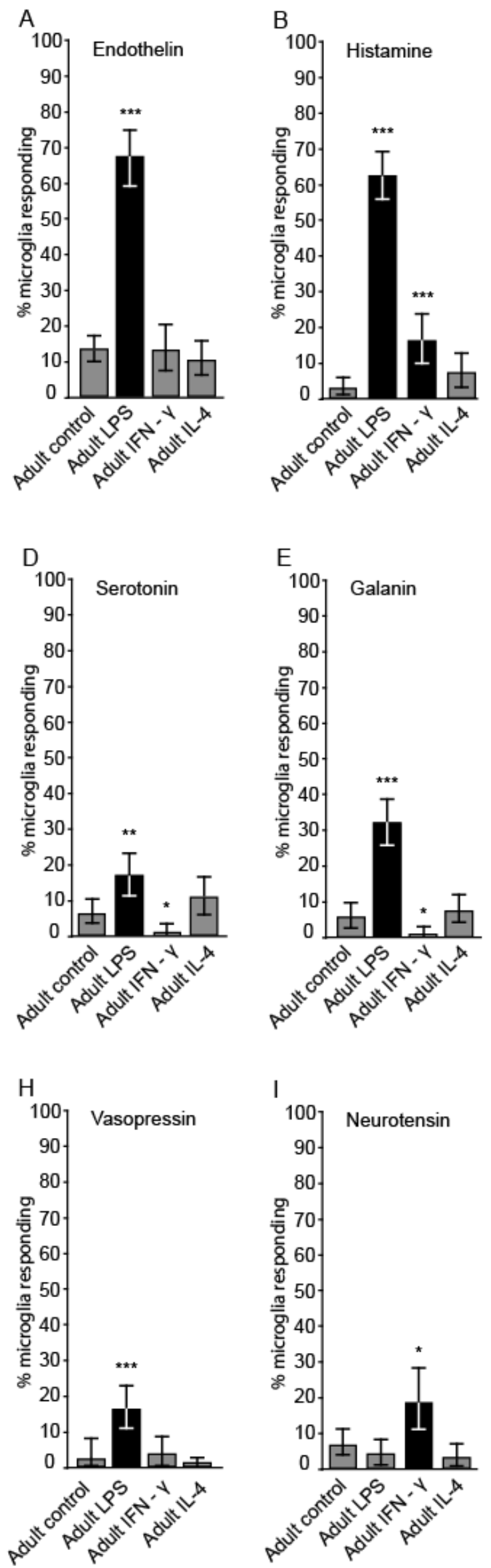

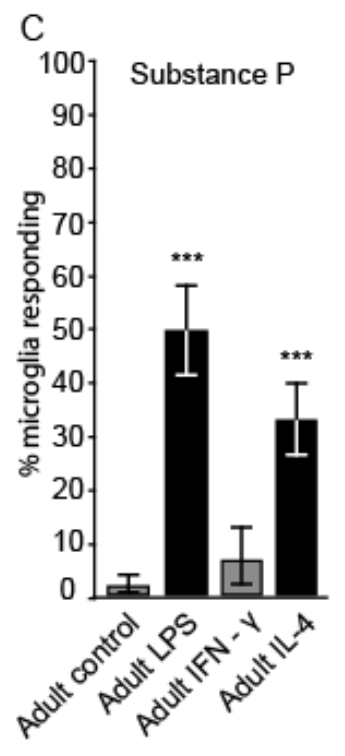

upregulation $\square$ no change
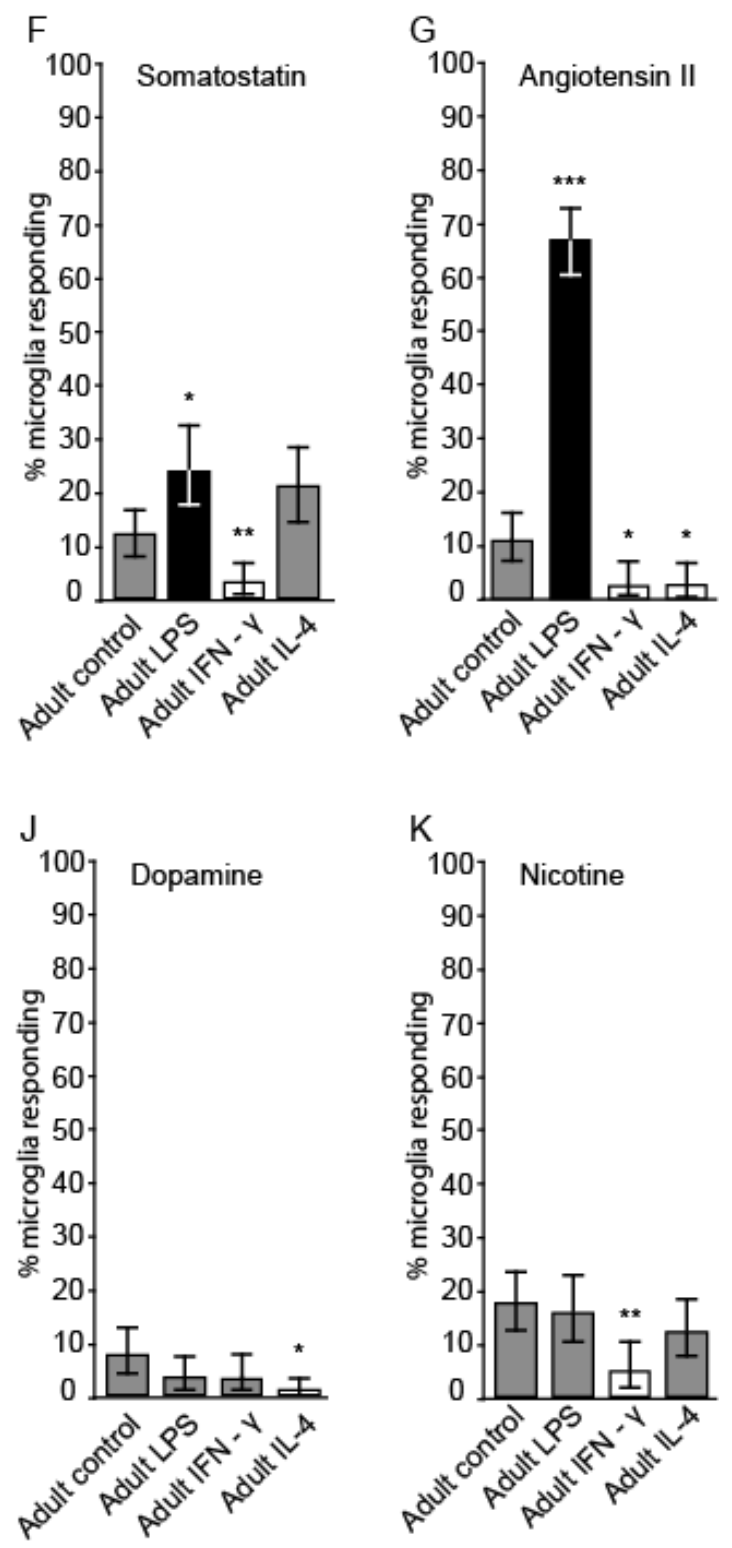
Figure 5

A

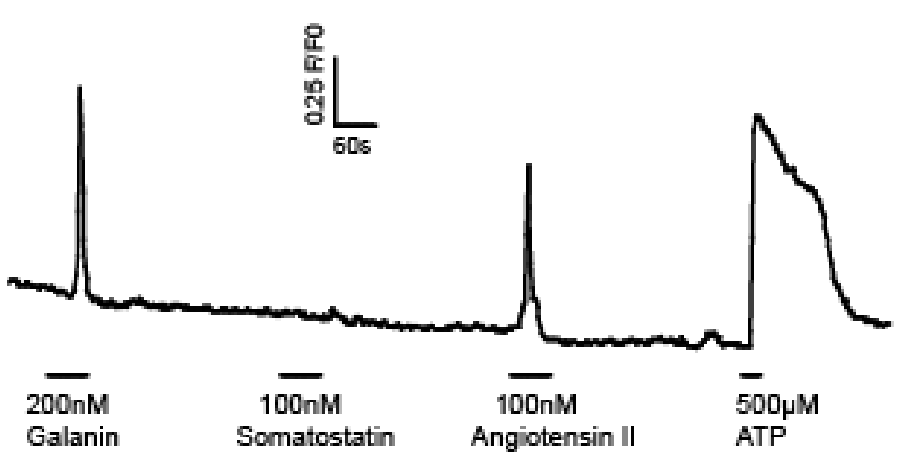

B

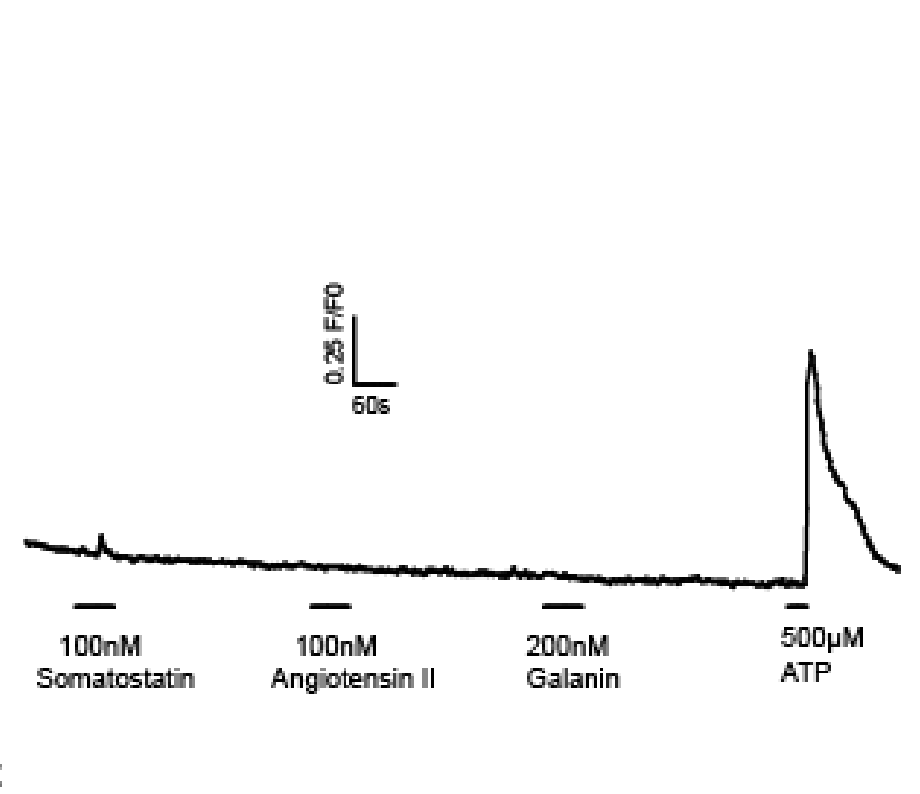

C

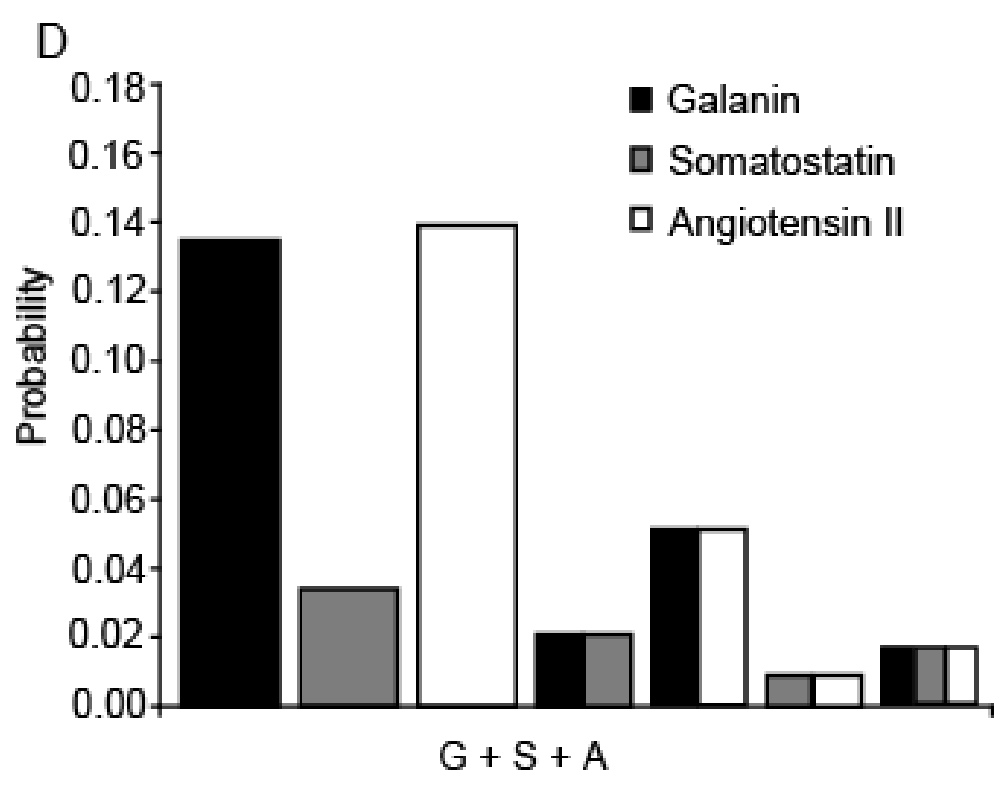

E

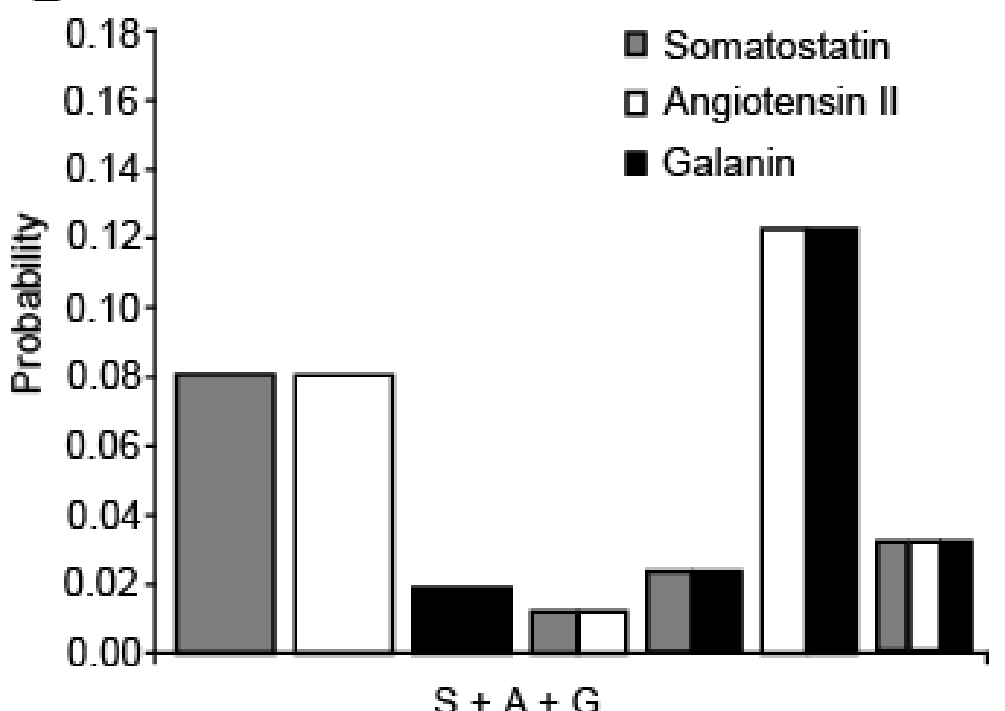

$\mathrm{F}$

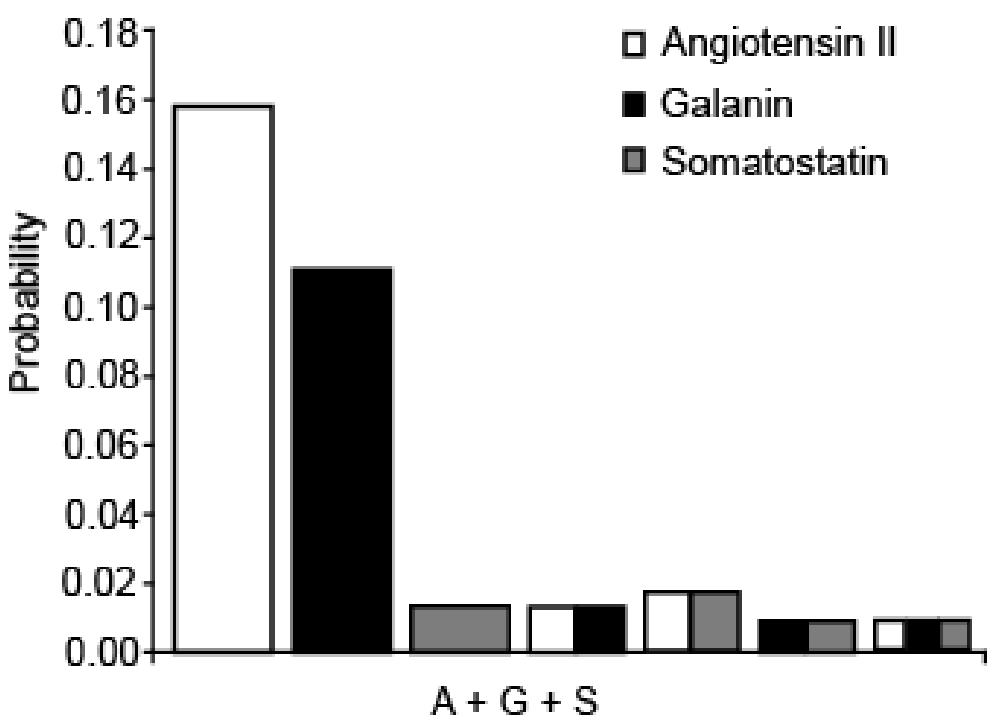


Figure 6

A

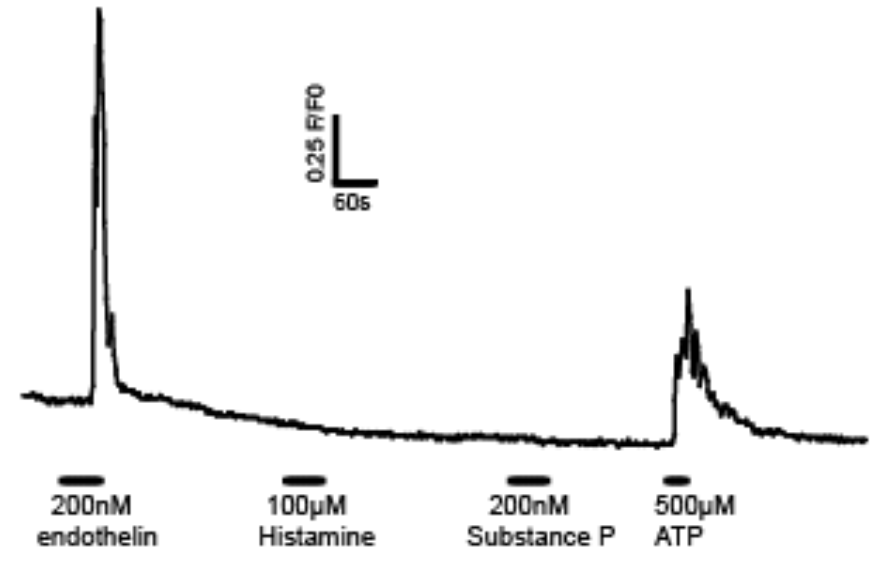

B

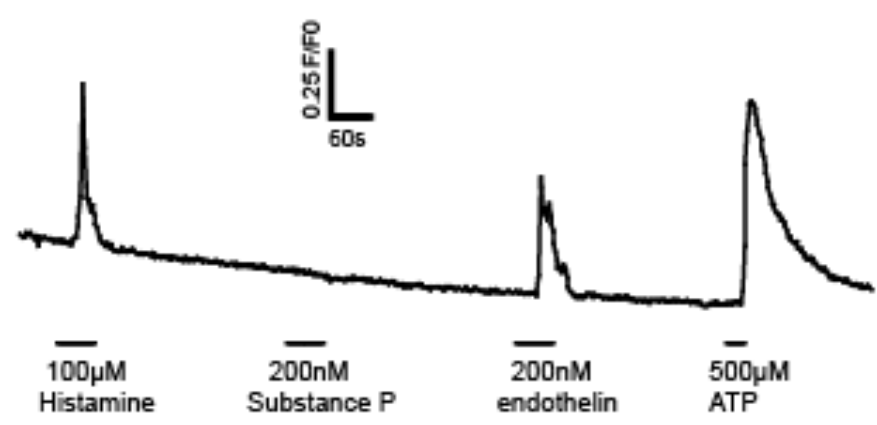

C

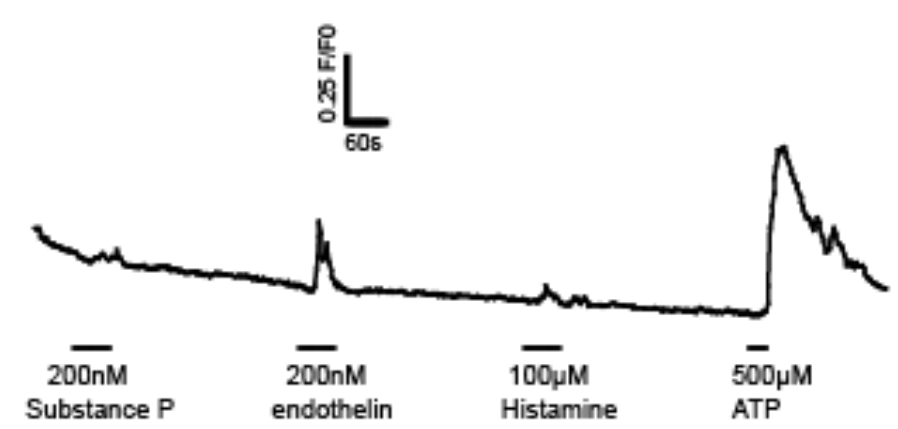

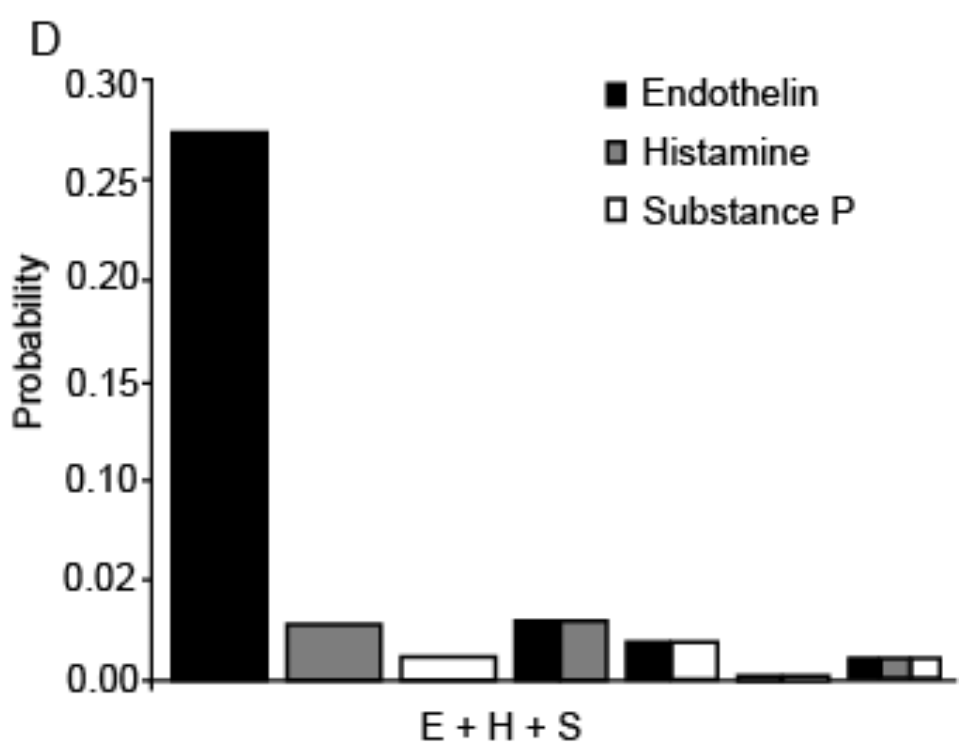

E
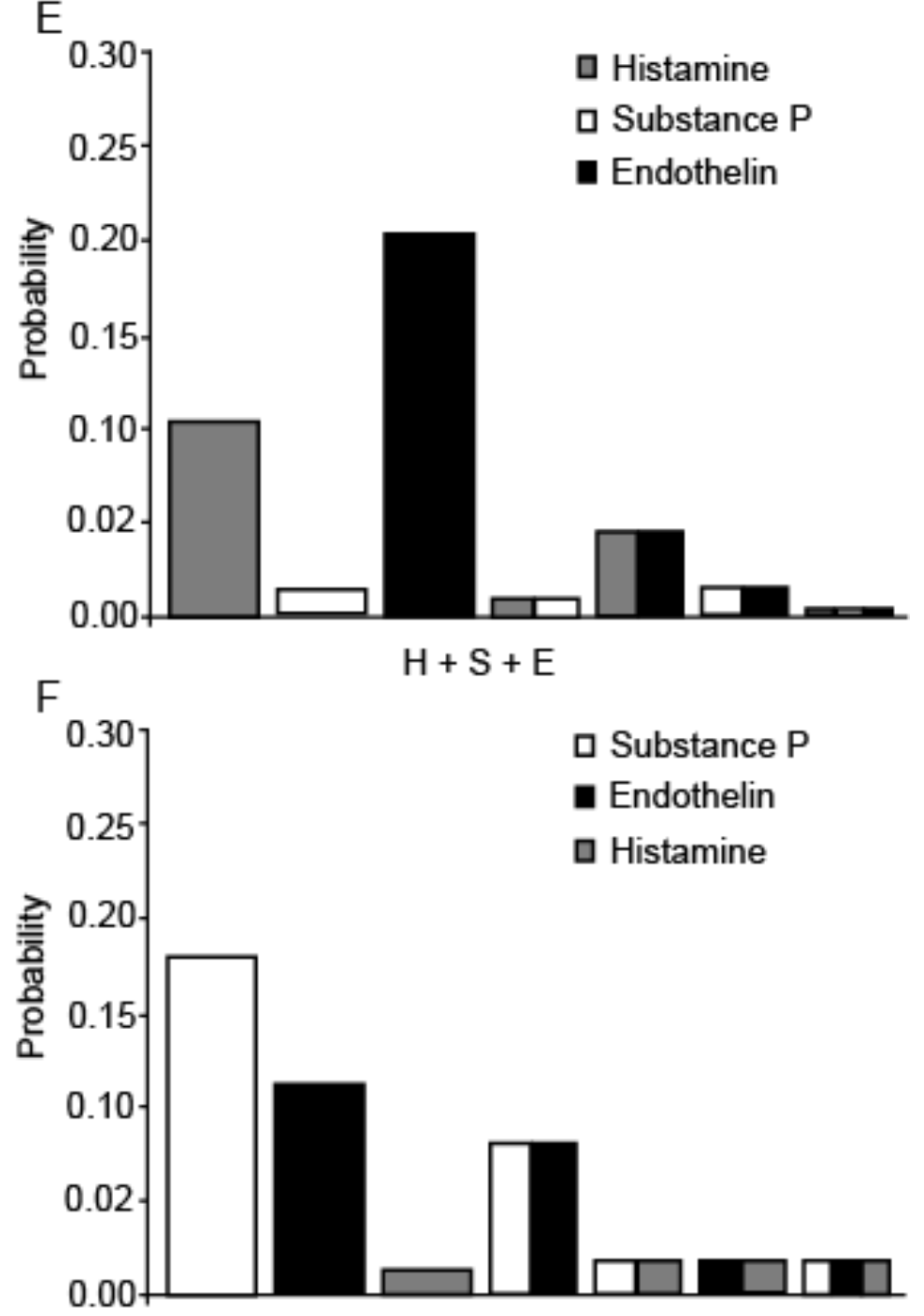

$\mathrm{S}+\mathrm{E}+\mathrm{H}$ 
Table 1 Mean integral, amplitude and duration of calcium transients in freshly isolated adult microglia

\begin{tabular}{llll}
\hline & $\begin{array}{l}\text { Mean integral of fluorescence change } \\
\text { as a \% of ATP response }( \pm \text { SEM) }\end{array}$ & $\begin{array}{l}\text { Mean amplitude as a \% of ATP } \\
\text { response }( \pm \text { SEM) }\end{array}$ & $\begin{array}{l}\text { Mean duration (s) } \\
( \pm \text { SEM) }\end{array}$ \\
\hline Endothelin & $57(18)$ & $85(4)$ & $53(16)$ \\
Histamine & $58(9)$ & $61(5)$ & $84(9)$ \\
Substance P & $51(7)$ & $93(7)$ & $58(7)$ \\
Serotonin & $41(8)$ & $74(6)$ & $72(9)$ \\
Galanin & $80(11)$ & $100(6)$ & $90(6)$ \\
Somatostatin & $56(6)$ & $70(4)$ & $85(8)$ \\
Angiotensin II & $48(5)$ & $69(3)$ & $76(5)$ \\
Vasopressin & $67(7)$ & $71(4)$ & $69(7)$ \\
Neurotensin & $52(6)$ & $66(5)$ & $73(6)$ \\
Dopamine & $60(7)$ & $68(6)$ & $82(6)$ \\
Nicotine & $56(9)$ & $62(6)$ & $83(7)$ \\
\hline
\end{tabular}


Table 2 Upregulation and downregulation of the response compared to control with fold change

\begin{tabular}{|c|c|c|c|c|c|c|}
\hline & \multicolumn{3}{|c|}{ Neonatal cultured } & \multicolumn{3}{|c|}{ Adult cultured } \\
\hline & LPS & IFN-y & IIL-4 & LPS & IFN-y & IL-4 \\
\hline Endothelin & 7.3 & 1.1 & 1.6 & 5.3 & 1.0 & 0.8 \\
\hline Histamine & 3.7 & 6.0 & 1.4 & 24.9 & 6.5 & 3.0 \\
\hline Substance $\mathrm{P}$ & 0.9 & 1.6 & 0.2 & 34.4 & 4.7 & 22.4 \\
\hline Serotonin & 1.0 & 0.2 & 0.3 & 2.8 & 0.2 & 1.7 \\
\hline Galanin & 0.6 & 5.6 & 0.4 & 5.9 & 0.3 & 1.3 \\
\hline Somatostatin & 2.7 & 4.9 & 1.0 & 2.0 & 0.3 & 1.7 \\
\hline Angiotensin II & 0.3 & 8.8 & 1.3 & 6.2 & 0.3 & 0.2 \\
\hline Vasopressin & 2.3 & 4.0 & 0.6 & $\overline{7.5}$ & 1.9 & 0.6 \\
\hline Neurotensin & 0.6 & 1.3 & 0.3 & 0.8 & 3.0 & 0.5 \\
\hline Dopamine & 1.6 & 2.8 & 0.8 & 0.5 & 0.5 & 0.2 \\
\hline Nicotine & 0.9 & 0.6 & 0.2 & 1.0 & 0.3 & 0.7 \\
\hline
\end{tabular}

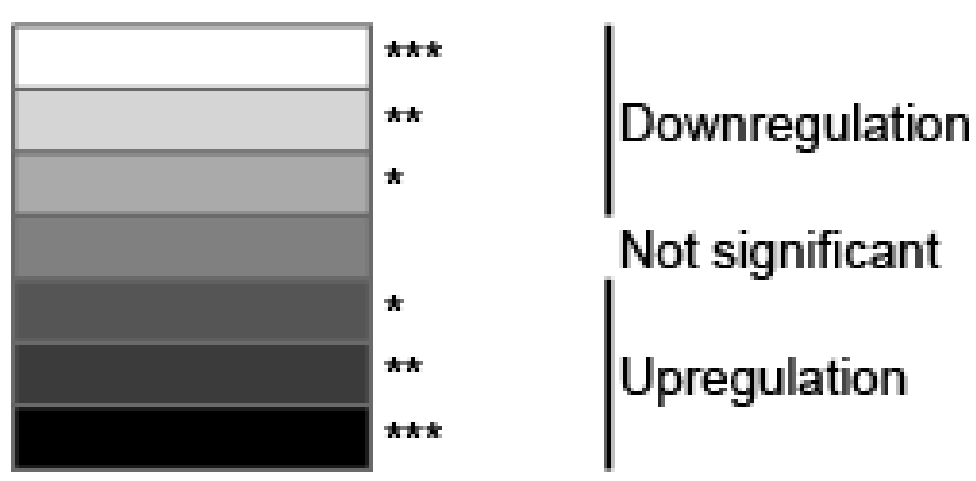


Table 3 Probability of single or combination response to galanin, somatostatin and angiotensin II

\begin{tabular}{|c|c|c|c|c|c|c|c|c|c|c|}
\hline & & & & & & & & \multicolumn{3}{|c|}{ All cells responding to - } \\
\hline & $\begin{array}{c}\text { Somatostatin } \\
\text { only }\end{array}$ & $\begin{array}{c}\text { Galanin } \\
\text { only }\end{array}$ & $\begin{array}{l}\text { Angiotensin } \\
\text { II only }\end{array}$ & $\begin{array}{c}\text { Angiotensin II + } \\
\text { Somatostatin }\end{array}$ & $\begin{array}{c}\text { Angiotensin II + } \\
\text { Galanin }\end{array}$ & $\begin{array}{c}\text { Somatostatin + } \\
\text { Galanin }\end{array}$ & $\begin{array}{c}\text { Angiotensin II + } \\
\text { Somatostatin + } \\
\text { Galanin }\end{array}$ & Somatostatin & Galanin & Angiotensin II \\
\hline$G+S+A$ & 0.034 & 0.135 & 0.139 & $0.008 \quad(0.017)$ & 0.051 (0.048) & $0.021 \quad(0.018)$ & $0.017 \quad(0.0039)$ & 0.080 & 0.224 & 0.215 \\
\hline$S+A+G$ & 0.081 & 0.021 & 0.081 & $0.013(0.038)$ & $0.123(0.051)$ & $0.025(0.031)$ & $0.034(0.0078)$ & 0.153 & 0.203 & 0.250 \\
\hline$A+G+S$ & 0.014 & 0.112 & 0.158 & $0.019(0.010)$ & $0.014(0.029)$ & $0.009(0.007)$ & $0.009(0.0015)$ & 0.051 & 0.144 & 0.200 \\
\hline
\end{tabular}

Table 4 Probability of single or combination response to endothelin, histamine and substance P

\begin{tabular}{|c|c|c|c|c|c|c|c|c|c|c|c|c|}
\hline \multirow[b]{3}{*}{$\mathrm{E}+\mathrm{H}+\mathrm{S}$} & \multirow{3}{*}{$\begin{array}{c}\begin{array}{c}\text { Endothelin } \\
\text { only }\end{array} \\
0.275\end{array}$} & \multirow{3}{*}{$\begin{array}{c}\begin{array}{c}\text { Histamine } \\
\text { only }\end{array} \\
0.026\end{array}$} & \multirow{3}{*}{$\begin{array}{c}\begin{array}{c}\text { Substance } \\
\text { P only }\end{array} \\
0.011\end{array}$} & \multirow[b]{2}{*}{$\begin{array}{c}\text { Endothelin + } \\
\text { Histamine }\end{array}$} & \multirow[b]{2}{*}{$\begin{array}{l}\text { Endothelin + } \\
\text { Substance P }\end{array}$} & \multirow{2}{*}{\multicolumn{2}{|c|}{$\begin{array}{l}\text { Histamine + } \\
\text { Substance P }\end{array}$}} & \multirow{2}{*}{\multicolumn{2}{|c|}{$\begin{array}{l}\text { Endothelin + } \\
\text { Histamine + } \\
\text { Substance P } \\
\end{array}$}} & \multicolumn{3}{|c|}{ All cells responding to - } \\
\hline & & & & & & & & & & Endothelin & Histamine & Substance $P$ \\
\hline & & & & $0.030(0.024)$ & $0.019(0.015)$ & 0.004 & $(0.003)$ & 0.011 & $(0.0011)$ & 0.335 & 0.071 & 0.045 \\
\hline $\mathrm{H}+\mathrm{S}+\mathrm{E}$ & 0.202 & 0.103 & 0.013 & 0.045 (0.043) & $0.013(0.011)$ & 0.009 & $(0.007)$ & 0.004 & $(0.0017)$ & 0.265 & 0.161 & 0.040 \\
\hline $\mathrm{S}+\mathrm{E}+\mathrm{H}$ & 0.112 & 0.013 & 0.179 & $0.018(0.015)$ & $0.080(0.067)$ & 0.018 & $(0.02)$ & 0.018 & $(0.0045)$ & 0.228 & 0.067 & 0.295 \\
\hline
\end{tabular}

